\title{
Pengaruh Formula Pupuk Organik Padat Berbasis Microbacter Alfaafa - 11 (MA-11) terhadap Pertumbuhan Tanaman Padi (Oryza sativa L.) di Kampung Prafi Mulya Distrik Prafi Kabupaten Manokwari
}

\author{
Saleh Rismeita Herlika ${ }^{1 *}$, Carolina Diana Mual ${ }^{1}$, Elwin ${ }^{1}$ \\ ${ }^{1}$ Jurusan Penyuluhan Pertanian, Program Studi Penyuluhan Pertanian Berkelanjutan, Politeknik \\ Pembangunan Pertanian Manokwari \\ *Corresponding author: salehrismeitaherlika@gmail.com
}

\begin{abstract}
Abstrak
Pupuk kompos didefinisikan sebagai pupuk yang terdiri dari bahan organik yang telah melalui proses rekayasa oleh mikroorganisme. Microbacter Alfaafa - 11 (MA-11) merupakan salah satu aktivator yang mampu merombak bahan organik dengan sangat cepat. Tujuan penelitian ini yaitu untuk mengetahui formulasi pupuk organik padat yang tepat untuk budidaya tanaman padi serta meningkatkan pengetahuan petani tentang teknik pembuatan pupuk organik padat dengan penambahan aktivator MA-11. Penelitian ini menggunakan Rancangan Acak Kelompok (RAK) non faktorial dengan 3 perlakuan, 6 ulangan dan 1 kontrol. Beberapa bahan organik yang digunakan adalah kotoran sapi (KS), sekam padi (SP), bonggol/batang pisang (BP), hijauan (daun gamal) (DG), dan bekatul (dedak) (D). Perlakuan kontrol (P0) tanpa pemberian pupuk organik, perlakuan 1 (P1) dengan formula 2:1:1:1:1 (KS:SP:BP:DG:D) dan perlakuan 2 (P2) dengan formula 1:2:1:1:1 (KS:SP:BP:DG:D). Parameter yang diamati yaitu tinggi tanaman padi, jumlah anakan dan kandungan hara pada tanah. Hasil penelitian menunjukkan bahwa formulasi dari pupuk organik padat yang tepat untuk pertumbuhan tanaman padi adalah formulasi 2:1:1:1:1 (P1) yang mana perlakuan tersebut berpengaruh secara nyata sesuai dengan hasil analisis RAK dan uji BNT.
\end{abstract}

Kata kunci: Pupuk organik, Ma-11, Formulasi, Tanaman padi

\begin{abstract}
Compost fertilizer is defined as a fertilizer that is mostly or entirely consist of organic materials that have been through the process of engineering by microorganisms. Microbacter Alfaafa - 11 (MA-11) is an activator capable of remodeling the organic material quickly. The purposes of this research are to know the formulation of solid organic fertilizer that is appropriate for rice cultivation and increase the knowledge of farmers about the technique of making solid organic fertilizer with the addition of Activator MA-11. This research uses non-factorial Randomized Block Design (RBD) with 3 treatments, 6 repeats, and 1 control. Some of the organic materials used are cow dung (KS), rice husk (SP), Banana rod (BP), forage (Gamal leaves) (DG), and Bran (Bran) (D). Treatment control $(P 0)$ without the provision of organic fertilizer, treatment $1(P 1)$ with formula 2:1:1:1:1 (KS: SP: BP:DG: D) and Treatment 2 (P2) with formula 1:2:1:1:1 (KS: SP: BP: DG: D). The observed parameters are rice crop height, number of saplings, and nutrient content on the soil. The results showed the best formulation of solid organic fertilizer for the growth of rice plants is a formulation of 2:1:1:1:1 (P1), in which the treatment is significantly affected according to the analysis (RBD) and Least Significant Difference test (LSD).
\end{abstract}

Keywords: Organic fertilizer, Ma-11, Formulation, Rice crop 
Prosiding Seminar Nasional Pembangunan dan Pendidikan Vokasi Pertanian Politeknik Pembangunan Pertanian Manokwari, 14 November 2020

e ISSN : 2774-1982

\section{PENDAHULUAN}

Tanaman padi (Oryza sativa L.) adalah tanaman penghasil beras yang merupakan sumber karbohidrat bagi sebagian penduduk dunia. Penduduk indonesia, hampir 95\% mengkonsumsi beras sebagai bahan pangan pokok dengan tingkat konsumsi rata-rata $114,13 \mathrm{Kg} / \mathrm{kapita} / \mathrm{tahun}$. Permintaan beras diperkirakan terus meningkat karena penambahan jumlah penduduk yang diperkirakan sebesar $1,49 \%$ per tahun. Saat ini luasan lahan tanaman padi di Indonesia pada tahun 2019 diperkirakan sebesar 10,68 juta hektar atau mengalami penurunan sebanyak 700,05 ribu hektar atau 6,15\% dibandingkan pada tahun 2018 dan produksi padi pada tahun 2019 diperkirakan sebesar 54,60 juta ton GKG atau mengalami penurunan sebanyak 4,60 juta ton atau 7,76\% dibandingkan pada tahun 2018. Jika produksi padi pada tahun 2019 dikonversikan menjadi beras untuk konsumsi pangan penduduk, produksi beras pada tahun 2019 sebesar 31,31 juta ton atau mengalami penurunan sebanyak 2,63 juta ton atau 7,75\% dibandingkan pada tahun 2018 (BPS, 2019).

Upaya peningkatan produksi padi harus terus menerus dilakukan melalui beberapa terobosan dalam peningkatan produksi dan produktivitas. (Direktorat Jendral Tanaman Pangan, 2016), Salah satu upaya dalam peningkatan produksi padi adalah dengan pemberian pupuk sesuai dengan kebutuhan tanaman. Pemanfaatan pupuk organik merupakan solusi selain untuk mengatasi kelangkaan pupuk anorganik juga dapat memperbaiki sifat-sifat dalam tanah. Penggunakan pupuk organik (berupa kompos) selalu mendapat perhatian semua kalangan karena bahan baku pembuatan kompos ini selalu tersedia secara berlimpah di sekitar areal pertanian. Kompos mampu memperbaiki sifatsifat fisik, kimiawi, dan biologi tanah. Sumber bahan kompos antara lain berasal dari limbah organik seperti sisa-sisa tanaman (jerami, batang, dahan, daun), sampah rumah tangga, kotoran ternak (sapi, kambing, ayam), arang sekam dan lain sebagainya. Pupuk organik digunakan bukan untuk menggantikan pupuk anorganik, tetapi sebagai komplemen, untuk meningkatkan produktivitas tanah dan tanaman secara berkelanjutan.

Permasalahan dilapangan petani masih sulit memanfaatkan kembali sisa tanaman untuk menyuburkan lahannya. Hal ini disebabkan karena secara alami perombakan limbah pertanian memerlukan waktu yang lama. Membuat kompos perlu mengatur dan mengontrol proses alami tersebut agar kompos dapat terbentuk lebih cepat. Hal ini dapat dilakukan dengan membuat campuran bahan yang seimbang, pemberian air secukupnya, mengatur aerasi dan penambahan aktivator. Setiap aktivator memiliki keunggulan masing-masing. MA-11 merupakan salah satu aktivator yang mampu merombak semua bahan organik dalam tempo sangat cepat dan dapat meningkatkan kandungan gizi yang 
Prosiding Seminar Nasional Pembangunan dan Pendidikan Vokasi Pertanian

Politeknik Pembangunan Pertanian Manokwari, 14 November 2020

e ISSN : 2774-1982

terkandung di dalam bahan (Artarizqi, 2013). Selain itu, MA-11 tersusun dari bakteri Rhizobium sp. yang dipadukan dengan berbagai bakteri yang diambil dari rumen sapi yaitu bakteri selulolitik, bakteri proteolitik dan bakteri amilolitik. Bakteri dari rumen sapi bertugas merombak selulosa agar mudah dikonsumsi oleh bakteri Rhizobium $s p$. yang beraktivitas mengikat nitrogen bebas.

Penelitian ini bertujuan untuk mengetahui formula dari pupuk organik padat yang tepat untuk budidaya tanaman padi serta meningkatkan pengetahuan petani tentang teknik pembuatan pupuk organik padat dengan penambahan aktivator MA-11.

\section{METODE}

Penelitian ini dilaksanakan selama 2 bulan terhitung bulan April - Mei 2020, yang berlokasi di Kampung Prafi Mulya Distrik Prafi Kabupaten Manokwari.

\section{Alat Dan Bahan}

Bahan yang digunakan dalam penelitian ini antara lain, kotoran sapi, bekatul (dedak), sekam padi, Bonggol/batang pisang dan hijauan (daun gamal) serta aktivator MA-11, gula pasir dan air.

Alat yang digunakan dalam penelitian ini antara lain adalah, terpal (ukuran $3 \mathrm{~m} \mathrm{x}$ $4 \mathrm{~m}$ ) sebagai tempat pengomposan, ember untuk tempat pengenceran dekomposer, Gelas ukur mengukur dekomposer dan air, Timbangan untuk mengukur berat bahan, sendok pengaduk untuk mencampur larutan dekomposer, pisau/parang untuk mencacah bahan, sekop/cangkul untuk mencampur semua bahan, gembor untuk penyiraman larutan dekomposer pada bahan.

\section{Rancangan Percobaan}

Penelitian ini menggunakan metode Rancangan Acak kelompok (RAK) dengan 3 perlakuan dan 6 kali ulangan terdiri dari kotoran sapi (KS), sekam padi (SP), bonggol/batang pisang (BP), hijauan (daun gamal) (DG), dan bekatul (dedak) (D), dengan rincian formulasi :

$\mathrm{P} 0=$ Tanpa pupuk (kontrol)

$\mathrm{P} 1=2: 1: 1: 1: 1(\mathrm{KS}: \mathrm{SP}: \mathrm{BP}: \mathrm{DG}: \mathrm{D})$

$\mathrm{P} 2=1: 2: 1: 1: 1(\mathrm{KS}: \mathrm{SP}: \mathrm{BP}: \mathrm{DG}: \mathrm{D})$

\section{Persiapan Bahan Baku Kompos}

1. Kotoran sapi (lebih bagus jika sudah mengalami pengomposan selama 2 minggu).

2. Bonggol/batang pisang dicacah menjadi notongan - potongan yang lebih kecil agar mempermudah proses pengomposan.

3. Hijauan (daun gamal), sekam padi dan bekatul (dedak).

4. Larutan aktivator MA-11, gula pasir dan air secukupnya. 
Prosiding Seminar Nasional Pembangunan dan Pendidikan Vokasi Pertanian

Politeknik Pembangunan Pertanian Manokwari, 14 November 2020

e ISSN : 2774-1982

5. Menurut (Nurman Ihsan, 2013) ada pedoman khusus : bila ingin membuat $10 \mathrm{~kg}$ pupuk bokashi diperlukan 2 tutup MA-11 ( $20 \mathrm{cc}$ ), 2 sendok gula pasir dan 1 liter air.

\section{Proses Pembuatan Pupuk}

1. Pembuatan larutan aktivator dengan melarutkan 12 tutup (120 cc) aktivator MA-11, 12 sendok gula pasir dan 6 liter air.

2. Untuk P1 (kotoran sapi $20 \mathrm{~kg}$, bonggol/batang pisang $10 \mathrm{~kg}$, daun gamal $10 \mathrm{~kg}$, sekam padi $10 \mathrm{~kg}$ dan bekatul 10kg) sedangkan P2 (kotoran sapi $10 \mathrm{~kg}$, sekam padi $20 \mathrm{~kg}$, bonggol/batang pisang $10 \mathrm{~kg}$, daun gamal 10kg dan bekatul 10kg).

3. Semua bahan yang telah siap dicampur hingga merata.

4. Tambahkan larutan aktivator (yang telah dicampur dengan gula pasir dan air)

5. Tumpuk bahan yang telah tercampur hingga ketinggian minimal $10 \mathrm{~cm}$.

6. Tutup menggunakan terpal.

7. Untuk mengatur sirkulasi udara setiap hari terpal harus dibuka dan pupuk diaduk kemudian tutup kembali.

8. Fermentasi pupuk selama kurang lebih 7 hari.

9. Pupuk yang telah siap dicirikan dengan berwarna gelap, kehitaman atau mirip seperti tanah, gembur, tidak panas dan tidak berbau.

\section{Parameter Yang Diamati}

Parameter yang diamati yaitu tinggi tanaman dan jumlah anakan tiap rumpun pada tanaman padi serta $\mathrm{C}$-organik, kandungan hara $(\mathrm{N}, \mathrm{P}, \mathrm{K})$, dan $\mathrm{pH}$ pada tanah sebelum dan sesudah pemberian pupuk organik.

Hasil penelitian tersebut kemudian di analisis menggunakan analisis Rancangan Acak Kelompok (RAK) dan di uji lanjut menggunakan uji Beda Nyata Terkecil (BNT).

\section{HASIL DAN PEMBAHASAN}

\section{Tinggi Tanaman Padi}

Hasil analisis pertambahan tinggi tanaman padi dapat di lihat pada tabel 1 .

Tabel 1. Analisis data pertambahan tinggi tanaman padi

\begin{tabular}{rrrrrrr}
\hline \multirow{2}{*}{ SK } & \multicolumn{7}{c}{ RAK/minggu } \\
\cline { 2 - 5 } & 1MST & 2MST & 3MST & 4MST & \multirow{2}{*}{ F 5\% } & \multirow{2}{*}{ Not } \\
\cline { 2 - 5 } & F Hit & F Hit & F Hit & F Hit & & \\
\hline Kelompok & 1,10 & 0,33 & 0,54 & 2,43 & 3,32 & tn \\
Perlakuan & 37,38 & 40,58 & 44,13 & 63,88 & 4,1 & $\mathrm{n}$ \\
\hline
\end{tabular}

Sumber : Data Terolah 2020

Tabel 1 menunjukkan bahwa $\mathrm{F}$ hitung $(63,88)>\mathrm{F}$ tabel 5\% $(4,1)$ sehingga perlakuan perbandingan formulasi berbeda nyata atau memberikan pengaruh yang 
Prosiding Seminar Nasional Pembangunan dan Pendidikan Vokasi Pertanian Politeknik Pembangunan Pertanian Manokwari, 14 November 2020

e ISSN : 2774-1982

signifikan terhahap pertambahan tinggi tanaman padi. Oleh karena itu, dilakukan uji lanjut dengan menggunakan uji Beda Nyata Terkecil (BNT), disajikan pada table 2.

Tabel 2. BNT pertambahan tinggi tanaman

\begin{tabular}{|c|c|c|c|c|c|c|c|c|}
\hline & \multicolumn{8}{|c|}{ Rata - rata } \\
\hline & \multicolumn{2}{|l|}{ 1MST } & \multicolumn{2}{|c|}{ 2MST } & \multicolumn{2}{|c|}{ 3MST } & \multicolumn{2}{|l|}{ 4MST } \\
\hline P0 & 15,16 & $\mathrm{a}$ & 20,10 & $\mathrm{a}$ & 25,57 & $\mathrm{a}$ & 31,24 & $\mathrm{a}$ \\
\hline P1 & 22,60 & $\mathrm{c}$ & 27,59 & $\mathrm{c}$ & 33,21 & $\mathrm{c}$ & 39,88 & $\mathrm{c}$ \\
\hline $\mathrm{P} 2$ & 18,27 & $\mathrm{~b}$ & 23,50 & $\mathrm{~b}$ & 29,21 & $\mathrm{~b}$ & 35,27 & b \\
\hline
\end{tabular}

Sumber : Data Terolah 2020

Unsur NPK yang diberikan merangsang proses fisiologi untuk pertambahan tinggi tanaman, seperti yang dinyatakan Lakitan (2000) bahwa pertambahan tinggi tanaman merupakan proses fisiologi dimana sel melakukan pembelahan. Pada proses pembelahan tersebut tanaman memerlukan unsur hara esensial dalam jumlah cukup yang diserap tanaman melalui akar.

Lingga (2003) menyatakan bahwa nitrogen dalam jumlah yang cukup berperan dalam mempercepat pertumbuhan tanaman secara keseluruhan, khususnya batang dan daun. Unsur nitrogen berperan dalam pembentukan sel, jaringan, dan organ tanaman. Unsur yang turut dalam pembelahan sel adalah unsur P. Adanya pembelahan dan perpanjangan mengakibatkan meningkatnya tinggi tanaman. Penambahan unsur K juga dapat memacu pertumbuhan tanaman pada tingkat permulaan, memperkuat ketegaran batang sehingga mengurangi resiko tidak mudah rebah (Lingga dan Marsono, 2003).

Pemberian pupuk organik padat dengan penambahan aktivator MA-11 dapat meningkatkan kadar N. Hal ini disebabkan oleh meningkatnya jumlah populasi bakteri Rhizobium sp. yang terdapat dalam aktivator MA-11 dan bersifat mengikat nitrogen bebas. Hal ini sesuai dengan pernyataan Palacious (2005), kinerja bakteri Rhizobium sp. yang terdapat pada aktivator MA-11 adalah mengikat nitrogen bebas. Bakteri dalam genus Rhizobium merupakan bakteri gram negatif, berbentuk bulat memanjang, yang secara normal mampu mengikat nitrogen dari atmosfer dan memiliki enzim nitrogenase yang dapat menggabungkan hidrogen dan nitrogen (Choudhury et al., 2004).

Penambahan aktivator MA-11 sebagai dekomposer juga mampu meningkatkan kadar P. Hal ini disebabkan bakteri proteolitik yang terdapat pada aktivator MA-11 mampu merombak protein pada bahan baku kompos menjadi asam amino. Hal ini sesuai dengan yang dikemukakan Subagiyo dan Setyati (2012), bakteri proteolitik memiliki kemampuan untuk menghasilkan enzim protease yang disekresikan ke lingkungan. Enzim 
Prosiding Seminar Nasional Pembangunan dan Pendidikan Vokasi Pertanian Politeknik Pembangunan Pertanian Manokwari, 14 November 2020

e ISSN : 2774-1982

proteolitik ekstraseluler bekerja menghidrolisis senyawa bersifat protein menjadi oligopeptida, peptida rantai pendek dan asam amino. Hal tersebut menyebabkan fosfat yang terikat dalam rantai panjang akan larut dalam asam organik yang dihasilkan oleh bakteri pelarut P, seberti bakteri Bacillus licheniformis dan Pseudomonas (Amanillah, 2011). Meningkatnya tinggi tanaman menunjukkan bahwa pemberian unsur $\mathrm{N}$, P, dan $\mathrm{K}$ secara bersamaan dapat menambah ketersediaan unsur hara dalam tanah sehingga turut berperan dalam pertumbuhan tanaman.

\section{Jumlah Anakan Tanaman Padi}

Pertambahan jumlah anakan pada tanaman padi dapat di lihat pada tabel 3.

Tabel 3. Analisis data pertambahan jumlah anakan tanaman padi

\begin{tabular}{|c|c|c|c|c|c|c|}
\hline \multirow{3}{*}{ SK } & \multicolumn{6}{|c|}{ Anova/minggu } \\
\hline & 1MST & 2MST & 3MST & 4MST & & Na \\
\hline & F Hit & F Hit & F Hit & F Hit & & \\
\hline Kelompok & 0,37 & 0,52 & 0,81 & 1,18 & 3,32 & tn \\
\hline Perlakuan & 9,24 & 10,29 & 12,30 & 16,37 & 4,1 & $\mathrm{n}$ \\
\hline
\end{tabular}

Sumber : Data Terolah 2020

Pada tabel 3 hasil analisis menunjukkan bahwa F hitung $(16,37)>\mathrm{F}$ tabel 5\% $(4,1)$ sehingga perlakuan perbandingan formulasi berbeda nyata atau memberikan pengaruh yang signifikan terhahap pertambahan jumlah anakan tanaman padi. Oleh karena itu, dilakukan uji lanjut dengan menggunakan uji Beda Nyata Terkecil (BNT), disajikan pada tabel 4 .

Tabel 4. BNT jumlah anakan tanaman padi

\begin{tabular}{lllllllrl}
\hline & \multicolumn{10}{c}{ Rata - rata } \\
\cline { 2 - 9 } & 1MST & \multicolumn{10}{c}{ 2MST } & 3MST & 4MST & \\
\hline P0 & 2,19 & a & 3,68 & a & 5,74 & a & 9,20 & a \\
P1 & 3,06 & c & 4,89 & c & 8,09 & $\mathrm{c}$ & 14,20 & c \\
P2 & 2,38 & ab & 3,95 & ab & 6,76 & ab & 11,45 & b \\
\hline
\end{tabular}

Sumber : Data Terolah 2020

Hasil uji BNT pada tabel 4 menunjukkan bahwa perlakuan perbandingan formula dari pupuk organik memberikan pertambahan jumlah anakan tanaman padi yang lebih baik Pertambahan jumlah anakan rata - rata terbesar pada perlakuan formulasi pupuk organik 2:1:1:1:1 (P1) sebesar 14,20 (4MST) berbeda nyata dengan perlakuan kontrol (P0) sebesar 9,20 (4MST) dan perlakuan formulasi pupuk organik 1:2:1:1:1 (P2) sebesar 11,45 (4MST). Pada 1MST sampai 3MST untuk perlakuan kontrol (P0) dan perlakuan 2 
Prosiding Seminar Nasional Pembangunan dan Pendidikan Vokasi Pertanian

Politeknik Pembangunan Pertanian Manokwari, 14 November 2020

e ISSN : 2774-1982

(P2) tidak berbeda nyata di lihat dari simbol huruf yang mengikuti. Hal ini disebabkan kandungan hara yang sudah ada pada P0 tidak jauh berbeda dari kandungan hara yang terdapat pada P2.

Kesuburan tanah merupakan salah satu faktor yang dapat menyebabkan bertambahnya jumlah anakan pada tanaman padi. Tanah yang telah diberikan pupuk organik berbasis MA-11 lebih gembur sehingga mempermudah akar tanaman untuk berkembang, hal ini disebabkan oleh bakteri yang terkandung dalam aktivator MA-11 yang mampu memperbaiki sifat fisik tanah.

Anakan tanaman padi adalah salah satu komponen yang menentukan hasil produksi dan membentuk rumpun, biasanya anakan akan tumbuh di dasar batang dan bersusun. Pertumbuhan anakan tanaman padi sangat dipengaruhi oleh pemberian pupuk yang dapat menyumbangkan unsur hara dan memenuhi hara tanaman sehingga dapat memberikan pertumbuhan anakan tanakan padi yang lebih optimal.

Unsur hara $\mathrm{P}$ merupakan unsur hara yang sangat dibutuhkan untuk pembentukan anakan. Hal ini sesuai dengan pengamatan Abdulrachman et al., (2009) bahwa hara P sangat diperlukan tanaman padi terutama pada saat awal pertumbuhan. Pada fase pertumbuhan tanaman tersebut, Unsur $\mathrm{P}$ berfungsi memacu pertumbuhan akar dan penambahan jumlah anakan.

\section{Kandungan Unsur Hara Dalam Tanah}

Tingkat kesuburan tanah diukur menggunakan Perangkat Uji Tanah Sawah (PUTS) untuk melihat tingkat kandungan unsur hara N (Nitrogen), P (Phosfor), K (Kalium) di tanah, serta $\mathrm{pH}$ tanah. Tingkat kandungan unsur hara tersebut ditunjukan secara kualitatif yaitu tingkat rendah (R), sedang (S), tinggi (T) dan sangat tinggi (ST) serta Masam (M). Pengujian dilakukan sebelum dan sesudah pemberian pupuk organik dengan jangka waktu 1 minggu. Hasil pengujian kandungan unsur hara dapat di lihat pada tabel 5.

Tabel 5. Tingkat kandungan unsur hara dalam tanah setelah pemberian pupuk organik

\begin{tabular}{cccccc}
\hline \multirow{2}{*}{ Perlakuan } & \multicolumn{5}{c}{ Variabel } \\
& C-Organik & $\mathrm{N}$ & $\mathrm{P}$ & $\mathrm{K}$ & $\mathrm{pH}$ \\
\hline P0 & Rendah & Tinggi & Sedang & Sedang & Masam \\
P1 & Sedang & Sangat Tinggi & Tinggi & Tinggi & Masam \\
P2 & Sedang & Tinggi & Sedang & Tinggi & Masam \\
\hline
\end{tabular}

Sumber : Data Primer 2020 
Prosiding Seminar Nasional Pembangunan dan Pendidikan Vokasi Pertanian Politeknik Pembangunan Pertanian Manokwari, 14 November 2020

e ISSN : 2774-1982

Pada tabel 5 menunjukkan variabel pada keadaan sebelum pemberian pupuk organik (P0) dibandingkan dengan sesudah pemberian pupuk organik dengan formulasi 2:1:1:1:1 (P1) maupun formulasi 1:2:1:1:1 (P2) secara kualitatif terjadi peningkatan.

Hanafiah (2013) menjelaskan bahwa bahan organik berfungsi untuk memperbaiki struktur tanah menjadi remah. Muyassir et al. (2012) menambahkan bahwa penambahan bahan organik dapat menurunkan berat isi tanah. Perbedaan nilai berat isi tanah dikarenakan adanya proses perbaikan sifat fisik tanah berkaitan dengan dekomposer yang merombak bahan organik. Indriani (2007) menjelaskan bahwa jumlah bahan organik yang terkandung di dalam tanah mempengaruhi perubahan berat isi tanah, dimana semakin banyak bahan organik maka berat isi semakin rendah dibanding tanah yang memiliki bahan organik yang rendah. Selain itu, aktivator MA-11 dalam proses dekomposer juga akan menyebabkan tanah semakin remah sehingga tanah lebih mudah diolah karena terdapat bakteri pengurai yang telah berkembang.

Selain penggunaan PUTS, untuk melihat kandungan unsur hara yang telah diserap oleh tanaman dilihat menggunakan Bagan Warna Daun (BWD). Penggunaan BWD (Bagan Warna Daun) untuk melihat kandungan $\mathrm{N}$ yang diperoleh tanaman. BWD merupakan alat skala warna daun yang terbuat dari plastik, terdiri atas 6 skala warna mulai dari skala 1 dengan warna hijau kekuningan hingga skala 6 dengan warna hijau tua. Semakin tinggi skala warna maka semakin tinggi kandungan $\mathrm{N}$ yang diterima oleh tanaman, serta semakin hijau warna daun maka kandungan klorofil pada daun semakin banyak sehingga proses fotosintesis semakin baik.

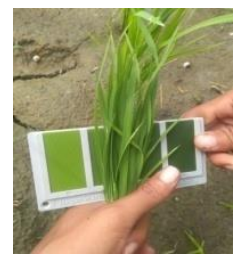

(P0)

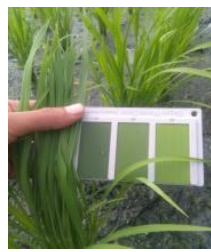

$(\mathrm{P} 1)$

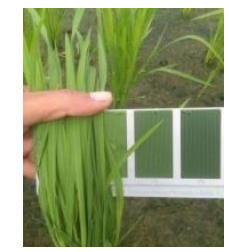

(P2)

Gambar 1. Bagan Warna Daun pada tanaman

Pada hasil menggunakan BWD untuk tanaman padi dengan formulasi 2:1:1:1:1 (P1) di dapat skala 3 sedangkan untuk perlakuan kontrol (P0) dan formulasi 1:2:1:1:1 (P2) mendapat skala 2 sehingga antara P0 dan P2 kandungan unsur hara yang di peroleh tanaman tidak berbeda. 


\section{KESIMPULAN DAN SARAN}

Berdasarkan hasil penelitian formulasi dari pupuk organik padat yang tepat untuk pertumbuhan tanaman padi adalah formulasi 2:1:1:1:1 (P1) yang mana perlakuan tersebut berpengaruh secara nyata sesuai dengan hasil analisis pada pertambahan tinggi dan jumlah anakan pada tanaman padi. Hal ini di karenakan kandungan unsur hara N, P dan K yang terkandung dalam pupuk organik dengan formulasi tersebut lebih banyak sehingga pertumbuhan tanaman padi semakin baik.

Perlu adanya penelitian lanjutan untuk mengembangkan variabel - variabel yang di amati sehingga data yang di peroleh semakin akurat dan efektif.

\section{UCAPAN TERIMA KASIH}

Terimakasih penulis sampaikan kepada kedua dosen pembimbing serta seluruh dosen Polbangtan Manokwari yang telah turut membantu dalam proses penelitian hingga proses penulisan laporan.

\section{DAFTAR PUSTAKA}

Abdulrachman, S., H. Sembiring \& Suyamto. (2009). Pemupukan Tanaman Padi. Balai Besar Penelitian Tanaman Padi. Pusat Penelitian dan Pengembangan Tanaman Pangan. Jakarta.

Amanillah, Zi. (2011). Pengaruh Konsentrasi EM4 pada Fermentasi Urin Sapi Terhadap Konsentrasi N, P dan K. Skripsi. Fakultas MIPA. Universitas Brawijaya. Malang.

Artarizqi, A.T. (2013). MA 11, Kolaborasi Mikroba Super. $<$ http://homeschoolingkaksetosemarang.com/article/99275/ma-11-kolaborasimikroba-super.html>. Di akses pada tanggal 28 Februari 2020.

BPS. (2019). Data luas panen dan produksi tanaman padi di indonesia https://www.bps.go.id/pressrelease/2020/02/04/438/luas-panen-dan-produksipadi-pada-tahun-2019-mengalami-penurunan-dibandingkan-tahun-2018-masingmasing-sebesar-6-15-dan-7-76-persen.html. Di akses pada tanggal 2 April 2020.

BPTP Kalteng. (2015). Membuat Kompos dengan Aktivator EM4. https://kalteng.litbang.pertanian.go.id/ind/index.php/publikasi-mainmenu-4747/teknologi/532-membuat-kompos-dengan-aktivator-em424. Di akses pada tanggal 28 Februari 2020.

Choudhury A.T.M.A. \& Kennedy I.R. (2004). Decomposition of Silicate Minerals by Bacillus Mucilaginous In Liquid Cultures. Environ Geochem and Health Journal (28): $133-140$.

D.J Tanaman Pangan. (2016). Upaya meninggkatkan produksi padi

Fisher. (1935). Metoda Fisher's LSD (Least Significance Difference) atau Uji Beda Nyata Terkecil (BNT).

Hanafiah, K.A. (2013). Dasar - dasar Ilmu Tanah. Rajawali Pers. Jakarta.

Indriani, Y.H. (2007). Membuat Kompos Secara Kilat. Penebar Swadaya. Jakarta. 
Prosiding Seminar Nasional Pembangunan dan Pendidikan Vokasi Pertanian

Politeknik Pembangunan Pertanian Manokwari, 14 November 2020

e ISSN : 2774-1982

Kurniawan, D., dkk. (2013). Pengaruh Volume Penambahan Effective Microorganism 4 (EM4) 1\% dan Lama Fermentasi Terhadap Kualitas Pupuk Bokashi dari Kotoran Kelinci dan Limbah Nangka. Jurnal Industria, 2(1), 57-66.

Kurniawan, H.N.A., dkk. (2014). Pengaruh Penambahan Konsentrasi Microbacter Alfaafa-11 (MA-11) dan Penambahan Urea Terhadap Kualitas Pupuk Kompos dari Kombinasi Kulit dan Jerami Nangka dengan Kotoran Kelinci. Jurusan Teknologi Industri Pertanian Fakultas Teknologi Pertanian Universitas Brawijaya. Malang.

Kompas. (2012). Nugroho Widiasmadi : Mencari Jawaban dengan Alfaafa https://nasional.kompas.com/read/2012/11/28/17224489/mencari.jawaban.denga n.alfaafa. Di akses pada tanggal 28 Februari 2020

Lakitan. (2011). Dasar - dasar Fisiologi Tumbuhan. Pt. Raja Grafindo Persada. Jakarta.

Lingga \& Marsono. (2003). Petunjuk Penggunaan Pupuk. Penebar Swadaya. Jakarta.

Medan Daily. (2016). pengolahan pupuk organik berbasis alfaafa, http://www.medanbisnisdaily.com/news/read/2016/06/20/241176/pengolahanpupuk-organik-berbasis-alfaafal . Di akses pada tanggal 20 Januari 2020.

Muyassir, Sufardi \& Saputra. (2012). Perubahan sifat fisika Inceptisol akibat perbedaan jenis dan dosis pupuk organik. Lentera 12 (1): 1-8.

Nurman Ihsan. (2013). Pedoman khusus pembuatan pupuk bokhasi dengan menggunakan MA-11.

Nyoman P. Aryantha, dkk. (2010). Peningkatan hasil produktivitas tanaman padi dengan pemberian pupuk organik.

Padmanagara. (2012). Bapak Penyuluhan Pertanian Pengabdi Petani Sepanjang Hayat, Cet. 1. Jakarta : PT Duta Karya Swasta.

Palacious, R. (2005). Genomes and Genomics of Nitrogen-Fixing Organisms. Springer. Dordrecht. Netherlands.

Sasongko. (2011). Pengaruh Media Penyuluhan Melalui Folder . Universitas Diponegoro. Kabupaten Semarang.

Subagiyo \& Setyati. (2012). Isolasi dan Seleksi Bakteri Penghasil Enzim Ekstraselular (proteolitik, amilolitik, lipolitik dan selulolitik) yang Berasal dari Sedimen Kawasan Mangrove. Jurnal Ilmu Kelautan, 17 (3): 164 - 168.

Wellang, R.M. (2015). Studi Kelayakan Kompos Menggunakan Variasi Bioaktivator (EM4 dan Ragi). Jurusan Sipil Fakultas Teknik. Universitas Hasanuddin. Makasar.

Yurmiati, H. (2012). Kualitas Pupuk Organik Hasil Biokonversi Limbah Peternakan Kelinci. Fakultas Peternakan Universitas Padjadjaran. Bandung. Hal 23-25. 